\title{
Shopping Motives, Mall Attractiveness, and Visiting Patterns in Shopping Malls in the Middle East: A Segmentation Approach
}

\author{
Mehmet Haluk Koksal \\ Professor of Marketing and Independent Business Consultant, Liverpool, England \\ haluk.koksal@gmail.com
}

\begin{abstract}
Middle Eastern consumers change their shopping behaviors in line with developments in global markets. Large-scale Western-style malls with various wellknown stores, shops, and cafes and restaurants have become shopping and attraction spaces. The purpose of the study is to segment Lebanese customers based on mall shopping motives. The data in the study were collected through a structured questionnaire distributed in the main shopping malls of the Lebanese capital, Beirut. A total of 300 mall customers were interviewed at mall exits. Respondents were intercepted by employing simple random sampling. The data were analyzed using exploratory factor and cluster analyses. This study revealed three main shopping motives: hedonic, efficiency, and accomplishment. It also identified three mall shopper segments: hedonists, achievers, and efficient shoppers. Each segment was also profiled in terms of mall attributes, visiting patterns, and demographics. The study clearly indicated significant differences among those segments. The study findings further indicated that the characteristics of different mall customer segments in Lebanon are in line with the studies conducted in other countries, although there are significant differences among the clusters. Identifying mall shopping motives and segmenting customers on those motives enables mall managers to develop appropriate retailing strategies to satisfy each segment.
\end{abstract}

Keywords: Mall shopping motivations, Shopping outcomes, Mall visiting patterns, Cluster analysis, Lebanon. 


\section{INTRODUCTION}

The shopping mall concept has increasingly gained more ground in retailing over the past six decades (Nicholls, Fuan, Kranendonk, \& Roscow, 2002; Southworth, 2005). Malls are emerging in greater numbers and changing the way customers like to shop ( $\mathrm{Li}$, Zhou, Nicholls, Zhuang, \& Kranendonk, 2004), especially in countries with an emerging economy. Malls have become the central point of community entertainment and contribute to a city's social and economic environments. Malls are of great importance for customers and the retail trade in any economy; they are also an important part of urban development. Shopping plays a pivotal role in consumers' lives, with malls not just being places for retail but also for socializing and entertainment. They not only contain shops but also private and public services such as banks, money exchange offices, health centers, libraries, citizen services, etc. Malls also offer a range of experiences such as cinemas, restaurants, coffee shops, and entertainment facilities.

Over the past several decades, retailing has become increasingly competitive. As the industry has matured, competition has grown in intensity and complexity, while consumer demand has changed and become more fragmented. This has led to the appearance of different specializations and formats in retailing, and, in such an environment, the understanding and prediction of consumer behavior are important subjects for retail research. Based on customer segmentation, managers can easily develop their marketing plans and strategies in order to satisfy the needs of various mall customers and ultimately obtain their loyalty (El Hedhli, Zourrig, \& Chebat, 2016).

Markets in the Middle East continue to attract an increasing number of international retailers, competing with established global retail centers. In line with the recent diffusion of global culture, Arab consumers enjoy shopping from large-scale malls with the extreme offering of a themed ambiance, multicultural restaurants, and luxurious Western products and brands. These developments have changed and reshaped the traditional shopping patterns of Arab consumers (Cherrier, Rahman, Mady, \& Lee, 2009; El-Adly, 2007). As a whole, the Middle East offers a great opportunity for mall retailing.

Surprisingly, the literature review indicates that only a few studies have been undertaken in the Middle East, despite the region attracting a plethora of foreign investors and multinational companies. This paper, therefore, attempts to investigate shopping motivations in Lebanon, one of the Middle Eastern countries, and to cluster Lebanese customers based on shopping motivations. The study also explores the customer characteristics in each segment based on mall attributes, visiting patterns, and socioeconomic characteristics. To achieve those objectives, this paper is divided into the following sections. First, the literature review is presented, followed by an explanation of 
the methodology employed in the study. Second, the findings of this study are explained. Third, the conclusions and implications are discussed for the industry and researchers, with limitations and suggestions for further research.

\section{LITERATURE REVIEW}

Market segmentation is one of the most traditional techniques used in marketing to understand customers, followed by market targeting and positioning. Market segmentation is defined as dividing a market into a distinct group of customers with different characteristics, needs, or behaviors who might require separate products or marketing mixes. Yankelovich and Meer (2006) argued that market segmentation, if properly applied, would guide companies in customizing their product and service offerings to the consumer groups most likely to purchase them. Market segmentation is generally considered as being more productive than treating the entire market in an undifferentiated manner (Dibb, Stern, \& Wensley, 2002). The process of segmentation assists marketers to strategically define target consumer groups and subsequently direct available resources to the most promising segments (McDonald \& Dunbar, 2012; Yankelovich \& Meer, 2006), each of which differs in a substantively meaningful way. Briefly, the rationale behind market segmentation is to provide better value to consumers and, in return, to increase company sales, market share, and profitability. The current study clusters mall consumers based on shopping motives, mall attributes, mall activities, and socio-economic characteristics.

\section{Shopping Motives}

Several studies in the literature have investigated underlying consumer shopping motivations. The earliest typology, by Stone (1954), identified four shopper groups: the "economic shopper" tends to give emphasis to price, quality, and variety of merchandise; the "personalizing shopper" looks for personal relationships in the context of shopping; the "ethical shopper" employs moral principles in the choice of stores; and the "apathetic shopper" shops out of necessity. Tauber (1972) categorized shopping motivations as personal and social motives. Personal motives include role-playing, diversion, selfgratification, learning about new trends, physical activity, and sensory simulation. Social motives for shopping involve social experiences outside the home, communication with others having a similar interest, peer group attraction, and status and authority. Bellenger, Robertson, and Greenberg (1977) identified the recreational shopper as well as the convenience (economic) shopper. Unlike the economic shopper, the recreational shopper 
seeks a recreational experience and gains satisfaction beyond that experienced by the actual products and services purchased.

Babin, Darden, and Griffin (1994) distinguished utilitarian motivations that are directed toward satisfying a functional or economic need, and hedonic shopping motivations that are recreation-, pleasure-, and simulation-oriented. Arnold and Reynolds (2003) identified six hedonic shopping motivations: adventure, social, gratification shopping, idea shopping, role shopping, and value shopping. The authors indicated that consumers go shopping to obtain a multitude of experiences such as thrill, excitement, and the ability to have an out-of-this-world experience charged with sounds, sights, and smells. Kim (2006) analyzed hedonic and utilitarian shopping motivations among inner city and non-inner-city shoppers based on the work of Arnold and Reynolds (2003). Alongside the six hedonic motivations, he grouped utilitarian motivations into two subdimensions: "achievement" and "efficiency." Indeed, many consumers today are becoming more concerned about efficiency due to time pressure. El-Adly and Eid (2015) introduced self-gratification, epistemic, social interaction, spatial convenience, transaction convenience, and time convenience values with hedonic and utilitarian values.

It can be concluded that numerous shopper typologies in the literature are based on shopping motives, which can be classified under two general motives: First, utilitarian shoppers are those who are practical in their purchases and seek to gratify their most utilitarian needs; this group has been identified as minimalists, serious, or mission shoppers (Gonzalez-Hernandez \& Orozco-Gomez, 2012). Second, hedonic shoppers regard the shopping mall as a place for social, entertainment, and leisure activities. This group has been labelled grazers, entertainment, recreational, relaxed, or full-experience shoppers. Table 1 presents a summary of the main shopping typologies with country, study focus, sample size, and main mall shopper segments. 
Table 1. Summary of Main Shopping Typologies

\begin{tabular}{|c|c|c|c|c|}
\hline Study & Country & Study focus & Sample size & Shopper types \\
\hline Stone (1954) & USA & Shopping motives & $\begin{array}{l}124 \text { female } \\
\text { department store } \\
\text { shoppers }\end{array}$ & $\begin{array}{ll}\text { - } & \text { Economic } \\
\text { - } & \text { Personalizing } \\
\text { - Ethical } \\
\text { - }\end{array}$ \\
\hline Tauber (1972) & USA & Shopping motives & $\begin{array}{l}30 \text { adult shoppers } \\
\text { interview }\end{array}$ & $\begin{array}{ll}\text { - Personal } \\
\text { - Social }\end{array}$ \\
\hline $\begin{array}{l}\text { Bellenger et al. } \\
\text { (1977) }\end{array}$ & USA & Shopping motives & $\begin{array}{l}324 \text { adult female } \\
\text { shoppers }\end{array}$ & $\begin{array}{ll}\text { - } & \text { Apathetical } \\
\text { - } & \text { Recreational } \\
\text { - } & \text { Functional }\end{array}$ \\
\hline $\begin{array}{l}\text { Babin et al. } \\
\text { (1994) }\end{array}$ & USA & Shopping motives & 404 shoppers & $\begin{array}{l}\text { - Utilitarian } \\
\text { - Hedonic }\end{array}$ \\
\hline $\begin{array}{l}\text { Bloch et al. } \\
\text { (1994) }\end{array}$ & USA & $\begin{array}{l}\text { Mall activities } \\
\text { Benefits }\end{array}$ & 600 adult shoppers & $\begin{array}{l}\text { - Mall enthusiasts } \\
\text { - Traditionalists } \\
\text { - Grazers } \\
\text { - Minimalists }\end{array}$ \\
\hline $\begin{array}{l}\text { Terblanch } \\
\text { (1999) }\end{array}$ & $\begin{array}{l}\text { South } \\
\text { Africa }\end{array}$ & Shopping benefits & $\begin{array}{l}1365 \text { shopping } \\
\text { centre shoppers }\end{array}$ & $\begin{array}{l}\text { - Functional } \\
\text { - Recreational } \\
\text { - Social }\end{array}$ \\
\hline $\begin{array}{l}\text { Arnold and } \\
\text { Reynolds (2003) }\end{array}$ & USA & $\begin{array}{l}\text { Hedonic shopping } \\
\text { motives }\end{array}$ & $\begin{array}{l}266 \text { adult store and } \\
\text { mall shoppers }\end{array}$ & $\begin{array}{l}\text { - Adventure } \\
\text { - Social } \\
\text { - Gratification } \\
\text { - Idea } \\
\text { - Role } \\
\text { - Value }\end{array}$ \\
\hline $\begin{array}{l}\text { Ruiz et al. } \\
\text { (2004) }\end{array}$ & Canada & $\begin{array}{l}\text { Mall activities } \\
\text { Psychographics } \\
\text { Perception } \\
\text { Emotion } \\
\text { Atmospherics } \\
\text { Density } \\
\text { Approach avoidance } \\
\text { reaction } \\
\text { Non-economic costs } \\
\text { Socio-demographic } \\
\text { characteristics }\end{array}$ & 889 adult shoppers & $\begin{array}{l}\text { - Recreational } \\
\text { - Full experience } \\
\text { - Browsers } \\
\text { - Mission }\end{array}$ \\
\hline Haanpaa (2005) & Finland & $\begin{array}{l}\text { Shopping motives } \\
\text { Socio-demographic } \\
\text { characteristics }\end{array}$ & $\begin{array}{l}1370 \text { adult } \\
\text { shoppers }\end{array}$ & $\begin{array}{ll}\text { - } & \text { Hedonic } \\
\text { - Recreational } \\
\text { - } \\
\text { - } \text { Convenient } \\
\end{array}$ \\
\hline Kim (2006) & USA & $\begin{array}{l}\text { Shopping motives } \\
\text { Store evaluative } \\
\text { criteria } \\
\text { Socio-demographic } \\
\text { characteristics }\end{array}$ & 662 adult shoppers & $\begin{array}{ll}\text { - } & \text { Alpha shopper } \\
\text { - Economic shopper } \\
\text { - } \text { Beta shopper } \\
\text { - Functional shopper } \\
\text { - Mission specialists }\end{array}$ \\
\hline
\end{tabular}


Table 1. Summary of Main Shopping Typologies (Con.)

\begin{tabular}{|c|c|c|c|c|}
\hline $\begin{array}{l}\text { Millan and } \\
\text { Howard (2007) }\end{array}$ & Hungary & $\begin{array}{l}\text { Shopping motives } \\
\text { Shopping values } \\
\text { Shopping enjoyment } \\
\text { Shopping behaviour } \\
\text { Socio-demographics } \\
\end{array}$ & 355 adult shoppers & $\begin{array}{ll}\text { - } & \text { Relaxed utilitarians } \\
\text { - } & \text { Strict utilitarians } \\
\text { - } & \text { Committed } \\
& \text { customers } \\
\text { - } & \text { Browsers } \\
\end{array}$ \\
\hline El-Adly (2007) & UAE & $\begin{array}{l}\text { Perceived mall } \\
\text { attributes } \\
\text { Visiting patterns } \\
\text { Socio-demographics }\end{array}$ & $\begin{array}{l}404 \text { university } \\
\text { personnel }\end{array}$ & $\begin{array}{l}\text { - Relaxed shoppers } \\
\text { - Demanding shoppers } \\
\text { - Pragmatic shoppers }\end{array}$ \\
\hline $\begin{array}{l}\text { Teller et al., } \\
(2008)\end{array}$ & Austria & $\begin{array}{l}\text { Shopping values } \\
\text { Perceived mall } \\
\text { attributes } \\
\text { Socio-demographics }\end{array}$ & $\begin{array}{l}1061 \text { adult } \\
\text { shoppers in a } \\
\text { shopping street and } \\
\text { 1081adult shoppers } \\
\text { in a mall }\end{array}$ & $\begin{array}{l}\text { - } \text { Pure hedonists } \\
\text { - Slight hedonists } \\
\text { - Slight utilitarians } \\
\text { - Pure utilitarians }\end{array}$ \\
\hline Gilboa (2009) & Israel & $\begin{array}{l}\text { Mall activities } \\
\text { Visiting patterns } \\
\text { Motivations } \\
\text { Socio-demographics }\end{array}$ & $\begin{array}{l}335 \text { adults from } \\
\text { malls and } 301 \\
\text { through phone } \\
\text { survey }\end{array}$ & $\begin{array}{ll}\text { - } & \text { Disloyal } \\
\text { - } & \text { Family bonders } \\
\text { - } & \text { Minimalists } \\
\text { - } & \text { Mall enthusiasts }\end{array}$ \\
\hline $\begin{array}{l}\text { Farrag et al. } \\
(2010)\end{array}$ & Egypt & $\begin{array}{l}\text { Motivations } \\
\text { Socio-demographics }\end{array}$ & 502 adult shoppers & $\begin{array}{ll}\text { - } & \text { Family focused } \\
\text { - Hedonists } \\
\text { - } & \text { Strivers } \\
\end{array}$ \\
\hline Gilboa (2012) & Israel & $\begin{array}{l}\text { Mall attributes } \\
\text { Mall activities } \\
\text { Visiting patterns } \\
\text { Socio-demographics }\end{array}$ & $\begin{array}{l}725 \text { respondents } \\
\text { through mall } \\
\text { survey }\end{array}$ & $\begin{array}{ll}\text { - } & \text { Enthusiasts } \\
\text { - } & \text { Recreationals } \\
\text { - Utilitarians }\end{array}$ \\
\hline $\begin{array}{l}\text { El-Adly and Eid } \\
(2015)\end{array}$ & UAE & Shopping motives & & $\begin{array}{ll}\text { - } & \text { Self-gratification } \\
& \text { Epistemic } \\
\text { - Social interaction } \\
\text { - Spatial convenience } \\
\text { - Transaction } \\
\text { - } \text { convenience } \\
\text { - Time convenience }\end{array}$ \\
\hline
\end{tabular}

\section{Mall Attributes}

Investigating what attributes make a shopping mall attractive has been the subject of many studies since the 1960s. Distance from the consumer's home and size of the shopping mall were found to be the most significant attributes in the first studies (Brunner \& Mason, 1968; Cox \& Cooke, 1970). However, studies at the end of the 1970s and beginning of the 1980s began employing multidimensional models by adding more cognitive attributes in order to better explain a shopping mall's attractiveness. These cognitive attributes have evolved into the concept of shopping mall image, which describes consumers' perceptions. For example, Mas-Ruiz (1999) identified three main attributes to measure shopping mall image: shopping environment, variety and professionalism, and parking. In another study (Sit et al., 2003), four main components of 
shopping mall image were recognized: merchandising, accessibility, services, and atmospherics. In a recent study, Tandon, Gupta, and Tripathi (2016) identified four groups of mall attractiveness factors in India, namely, atmospherics, entertainment, tenant management, and facilities management.

Consumers evaluate shopping malls based on different attributes or dimensions. For example, Singh and Sahay (2012); Wong, Wong, and Wong (2012); and Jackson, Stoel, and Brantley (2011) found convenience and location to be the most important mall attributes. Michon, Yu, Smith, and Chebat (2008) and Anselmsson (2006) identified mall atmosphere as one of the significant dimensions. Some studies stressed the significance of the presence of anchor stores (Shanmugan, 2013; Damian, Curto, \& Pinto, 2011; Finn, 1996), variety of stores, or tenant mix (Chebat, Sirgy, \& Grzeskowiak 2010; El-Adly, 2007; Lee, Ibrahim, \& Hsueh-Shan 2005) and retail assortment (Chebat et al., 2010; Yilmaz, 2004; Frasquet, Gil, \& Molla 2001). Unsurprisingly, malls perceived to have stores with acceptable prices are more likely to be favoured by shoppers than malls with stores having unacceptable prices (Chebat et al., 2010; Yilmaz, 2004). Others (Sit \& Birch, 2014; Jackson et al., 2011; Lotz, Eastlick, Mishra, \& Shim, 2010) found that entertainment was one of the attractiveness attributes for the malls. Special events such as cultural performances, exhibitions, fashion shows, and parties were also found to be essential mall attributes (Lee et al., 2005). As the literature review indicates, while there is no consensus on the attributes that attract consumers to malls, there is a group of dimensions common to several studies. It is also evident that the existence of certain mall attributes leads to positive customer satisfaction and behavioral intentions. For example, El Hedhli et al. (2016) concluded that, if customers experience pleasurable moments and enjoyable activities during their shopping trips to malls, they will develop more positive attitudes toward malls that will ultimately be transformed into positive behavioral responses such as positive word of mouth. Khong and Ong (2014) also identified that customer perception of the style, variety, and quality of the products and services in the shopping mall results in patronage loyalty.

\section{Visiting Pattern}

"Visiting pattern" refers to aspects of visitors' behavior such as frequency of trips to the mall, time spent at the mall, the number of malls visited, and mall companions (Millan \& Howard, 2007; El-Adly, 2007). For example, mall customers tend to buy more products and spend more money when accompanied by a friend or relative (Borges, Chebat, \& Babin, 2010; Nicholls et al., 1997). Purchases made during shopping trips can be either planned or unplanned. There is also a positive relationship between the time and 
money spent in malls: The longer visitors stay in malls, the more money they spend (Kuruvilla \& Joshi, 2010). Some studies (Li et al., 2004; Nicholls et al., 1997) revealed that the frequency of shopping, shopping duration, and time significantly affect shopping behavior. Cai and Shannon (2012) found that consumers' attitudes toward mall attributes relate positively with their shopping intention, which also has a positive effect on their shopping frequency and money spent in the mall.

\section{Country Background}

As the relative proportion of the various sects is politically sensitive, Lebanon has not collected official census data on ethnic background since 1932 under the French Mandate. It is therefore difficult to conduct an exact demographic analysis of Lebanese society. Its population is estimated to be around 6 million.

Lebanon is a service-based economy. Between 1997 and 2008, growth was driven by three sectors: retail and wholesale trade, telecoms, and banking. The retail and wholesale trade sectors have contributed $9.4 \%$ to the Lebanese economy over the past decade (Mottu \& Nakhle, 2010). Lebanon is also grouped as an "upper-middle income" economy by the World Bank with a per capita income of over $\$ 8,000$. Although there are no official statistics in the country, it is believed that around 5\% of the Lebanese population is extremely wealthy and can afford a luxurious and lavish lifestyle, while $30 \%$ to $40 \%$ of the population belongs to the middle-income class who are affluent enough to pursue a quality lifestyle and demand branded products. The Lebanese themselves are extremely concerned with appearance and image, so they spend a lot of money to stay abreast of the latest fashion trends and fashion lines (Sharif, 2017). In the elite of Lebanese society, the most important thing is to see and be seen (Sherlock, 2015). The Lebanese are adaptive to Western culture and this type of lifestyle. Beirut, which is the capital of Lebanon, has long been known as the fashion and lifestyle trendsetter of the Middle East.

Shopping malls have become a key part of district renewal. The concept of a singularly owned and operated multitenant commercial property is thriving. The shopping mall industry forms an important player in the Lebanese economy and society. As a principal facilitator of retail sales, it is a major contributor to private consumption and receives a significant amount of investment. Moreover, the shopping mall industry generates employment among young adults and is a critical source of flexible working opportunities for students (Blominvest Bank Report, 2015). Although it has recently attracted many investors to build modern shopping malls and other types of shopping 
centers, political tension due to the conflicts in the region pose a major threat to this industry.

\section{RESEARCH METHODOLOGY}

\section{Data Collection Method and Research Sample}

The data in the study were collected through a structured questionnaire distributed in the main shopping malls in Beirut in 2017. Respondents were intercepted by employing systematic random sampling in order to have a more representative sample. Mall customers were interviewed at mall exits. Three hundred people were surveyed, of which 174 were female and 126 were male. Respondents with university and higher degrees represented more than $80 \%$ of the sample. Of the sample, $55 \%$ respondents were single and $45 \%$ married; almost $70 \%$ of the respondents were younger than 40 years old. Public and private sector employees were the majority of the sample with $37 \%$. Table 2 presents respondent profiles.

Table 2. Sample Characteristics

\begin{tabular}{|c|c|c|c|c|c|}
\hline Gender & $\mathrm{n}$ & $\%$ & Marital Status & $\mathrm{n}$ & $\%$ \\
\hline Female & 174 & 58.0 & Single & 165 & 55.0 \\
\hline Male & 126 & 42.0 & Married & 135 & 45.0 \\
\hline Total & 300 & 100.0 & Total & 300 & 100.0 \\
\hline Age & $\mathrm{n}$ & $\%$ & Occupation & $\mathrm{n}$ & $\%$ \\
\hline Younger than 20 & 46 & 15.3 & Student & 72 & 24.0 \\
\hline $20-29$ & 105 & 35.0 & Public and private sector emp. & 111 & 37.0 \\
\hline $30-39$ & 57 & 19.0 & Self-employed & 57 & 19.0 \\
\hline 40 and older & 92 & 30.7 & Others & 60 & 20.0 \\
\hline Total & 300 & 100.0 & Total & 300 & 100.0 \\
\hline Education & $\mathrm{n}$ & $\%$ & $\begin{array}{l}\text { Income level (US dollars) per } \\
\text { month }\end{array}$ & $\mathrm{n}$ & $\%$ \\
\hline Secondary and less & 56 & 18.6 & Less than $\$ 750$ & 91 & 30.3 \\
\hline University & 178 & 59.4 & $\$ 751-\$ 1500$ & 82 & 27.4 \\
\hline Master and Ph.D. & 66 & 22.0 & Higher than $\$ 1500$ & 127 & 42.3 \\
\hline Total & 300 & 100.0 & Total & 300 & 100.0 \\
\hline
\end{tabular}

\section{Research Variables}

A questionnaire, available in both English and Arabic and consisting of four sections, was formulated to collect the data for the research. In the first section, the respondents indicated their agreement level for statements about their mall shopping motives on a 7- 
point Likert scale, which ranged from 1: strongly disagree to 7: strongly agree. Babin et al. (1994) adopted the mall shopping motives. In the second section, the mall attributes were developed for this study, and respondents were asked to evaluate 13 attractive mall attributes on a 7-point Likert-type scale, ranging from 1: not at all to 7: very likely. The third section included variables regarding visiting patterns such as frequency of visit, the amount of time and money spent in the mall, and the number of stores visited. They were measured with the ordinal scales. This section also contained the question of whether this visit was planned or spontaneous. It was evaluated with dichotomous scales. The last part of the questionnaire included six socio-demographic characteristics of the respondents, including gender, age, marital status, education level, occupation, and income level.

\section{RESULTS}

Factor analysis with varimax rotation was applied to the shopping motivations in order to reduce the large number of independent variables into a meaningful and smaller number of subsets or factor groups. In order to have practical significance, an item requires an absolute loading value of at least 0.5 (Hair, Black, Babin, \& Anderson, 2014). Thus, the items with factor loadings below 0.5 were dropped from the analysis.

According to the analysis results, the shopping motivations were grouped under three headings: hedonic, efficiency, and accomplishment shopping motivations. Factor analysis explains almost $66.6 \%$ of the total changes in variations. The Kaiser-MeyerOlkin statistic is the measure of sampling adequacy. Kaiser states values greater than .05 are acceptable, values between 0.8 and 0.9 are great, and between 0.9 and 1.0 are superb. For these data, the value of $\mathrm{KMO}$ is 0.89 , which falls into the range of being great. Bartlett's test, $\chi^{2}(105)=2619.457 p<0.001$ indicated that the correlations between items were sufficiently large enough to proceed with the factor analysis. Reliability of the scale prepared for shopping motivations was measured through the co-efficiency of Cronbach's alpha for each subscale. They were between 0.93 to 0.60 , which is an acceptable level for further analysis. Table 3 presents the factor analysis results based on shopping motivations. 
Table 3. Factor Analysis Results Regarding Shopping Motivations

\begin{tabular}{|l|r|r|c|}
\hline Shopping motivations & $\begin{array}{r}\text { Factor } \\
\text { Loading }\end{array}$ & $\begin{array}{c}\text { Variance } \\
\%\end{array}$ & $\begin{array}{c}\text { Cronbach's } \\
\text { Alpha }\end{array}$ \\
\hline Hedonic motivations & & 44.398 & .934 \\
\hline $\begin{array}{l}\text { I had a good time because I was able to act on the } \\
\text { spur-of-the moment }\end{array}$ & .839 & & \\
\hline This shopping trip truly felt like an escape & .837 & & \\
\hline $\begin{array}{l}\text { Compared to other things I could have done, the time } \\
\text { spent shopping was truly enjoyable }\end{array}$ & .835 & & \\
\hline This shopping trip was truly a joy & .816 & & \\
\hline $\begin{array}{l}\text { I enjoyed this shopping trip for its own sake, not just } \\
\text { for the items I may have purchased }\end{array}$ & .807 & & \\
\hline $\begin{array}{l}\text { I continued to shop, not because I had to, but because } \\
\text { I wanted to }\end{array}$ & .787 & & \\
\hline During the trip, I felt the excitement of the hunt & .771 & & \\
\hline I enjoyed being emerged in exciting new products & .734 & & \\
\hline While shopping, I was able to forget my problems & .732 & & \\
\hline While shopping, I felt a sense of adventure & .729 & & \\
\hline Efficiency & & 14.139 & .600 \\
\hline I couldn't buy what I really needed & .824 & & \\
\hline $\begin{array}{l}\text { I was disappointed because I had to go to another } \\
\text { store(s) to complete my shopping trip }\end{array}$ & .762 & & \\
\hline This shopping trip was not a very nice time out & .556 & & \\
\hline Accomplishment & & 8.116 & .710 \\
\hline $\begin{array}{l}\text { I accomplished just what I wanted to on this shopping } \\
\text { trip }\end{array}$ & .855 & & \\
\hline $\begin{array}{l}\text { While shopping, I found just the item(s) I was looking } \\
\text { for }\end{array}$ & .833 & & \\
\hline
\end{tabular}

Cluster analysis is applied after factor analysis because the objective of the paper is to segment respondents into distinctive groups according to their shopping motivations. Two-step hierarchical cluster analysis was employed following the suggestions by Punj and Steward (1983). This type of analysis combines the hierarchical analysis method of Ward with the nonhierarchical $k$-means clustering procedure.

First, Ward's method with the squared Euclidean distance was used to identify the number of clusters within the sample. An examination of the agglomeration schedule as 
well as dendogram suggested three clusters to be most appropriate in order to segment the sample. The second step involved a nonhierarchical $k$-means analysis on the three-cluster solution. The ANOVA analysis confirmed the significance of group differences; all observed F statistics exceeded critical values at the 0.001 significance level, and the post hoc procedure (Scheffe test) revealed that the clusters were statistically different with respect to the three shopping motivations. Table 4 exhibits the cluster differences in the shopping motivation dimensions.

According to the nonhierarchical $k$-means analysis results, Cluster 1 comprises $30 \%$ of the sample and had the highest mean score on hedonic shopping motivation. Therefore, it is called the hedonic customer group. Cluster 2 makes up $40 \%$ of the sample. This cluster is termed the apathetic customer group because it had the lowest mean score on every shopping motivation. Finally, Cluster 3 contains 30\% of the sample and had the highest score on efficiency and achievement. Hence, it is named as the utilitarian shoppers group.

To understand the clusters in detail, cluster differences in mall attributes were tested using one-way ANOVA analysis. ANOVA analysis results indicated that the cluster groups significantly differed in terms of almost all the mall attribute dimensions except easy parking and providing security. The hedonist shoppers group had the highest scores on all mall attributes except being easy to park. These shoppers especially enjoyed having a wide assortment of merchandise and well-known brands, along with providing favorite speciality shops. The utilitarian shoppers group had the highest scores on the mall attributes after the hedonic shoppers group. They particularly liked offering high-quality merchandise, having a wide assortment of merchandise, having well-known brands, and being easy to park. The apathetic customers group scored the lowest on every mall attribute. Table 5 shows the cluster's differences regarding the mall attributes. 
Table 4. Cluster Differences Based on Mall Shopping Motivations

\begin{tabular}{|c|c|c|c|c|}
\hline Mall shopping motivations & $\begin{array}{c}\text { Hedonic } \\
\text { shoppers } \\
(\mathrm{n}: 90)\end{array}$ & $\begin{array}{c}\text { Apathetic } \\
\text { shoppers } \\
\text { (n:120) }\end{array}$ & $\begin{array}{c}\text { Utilitarian } \\
\text { shoppers } \\
\text { (n: 90) }\end{array}$ & $F$ value \\
\hline Hedonic & 5.24 & 2.98 & 4.62 & $183.834^{* * * *}$ \\
\hline $\begin{array}{l}\text { I had a good time because I was } \\
\text { able to act on the spur-of-the } \\
\text { moment }\end{array}$ & 5.00 & 2.78 & 4.18 & $86.637^{* * *}$ \\
\hline $\begin{array}{l}\text { This shopping trip truly felt like } \\
\text { an escape }\end{array}$ & 5.47 & 2.97 & 5.02 & $122.915^{* * *}$ \\
\hline $\begin{array}{l}\text { Compared to other things I could } \\
\text { have done, the time spent } \\
\text { shopping was truly enjoyable }\end{array}$ & 5.36 & 3.17 & 4.88 & $76.013^{* * *}$ \\
\hline This shopping trip was truly a joy & 5.52 & 3.10 & 5.23 & $110.100^{* * *}$ \\
\hline $\begin{array}{l}\text { I enjoyed this shopping trip for its } \\
\text { own sake, not just for the items I } \\
\text { may have purchased }\end{array}$ & 5.54 & 3.16 & 4.95 & $95.670^{* * *}$ \\
\hline $\begin{array}{l}\text { I continued to shop, not because I } \\
\text { had to, but because I wanted to }\end{array}$ & 5.52 & 3.10 & 4.73 & $73.294^{* * * *}$ \\
\hline $\begin{array}{l}\text { During the trip, I felt the } \\
\text { excitement of the hunt }\end{array}$ & 4.83 & 2.67 & 3.86 & $60.036^{* * *}$ \\
\hline $\begin{array}{l}\text { I enjoyed being immersed in } \\
\text { exciting new products }\end{array}$ & 5.07 & 2.85 & 4.29 & $64.442^{* * * *}$ \\
\hline $\begin{array}{l}\text { While shopping, I was able to } \\
\text { forget my problems }\end{array}$ & 5.42 & 3.20 & 5.35 & $103.912^{* * * *}$ \\
\hline $\begin{array}{l}\text { While shopping, I felt a sense of } \\
\text { adventure }\end{array}$ & 4.63 & 2.61 & 3.72 & $50.595^{* * *}$ \\
\hline Efficiency & 4.22 & 3.91 & 5.94 & $70.638^{* * * *}$ \\
\hline $\begin{array}{l}\text { I couldn't buy what I really } \\
\text { needed }\end{array}$ & 3.92 & 4.01 & 6.02 & $71.285^{* * *}$ \\
\hline $\begin{array}{l}\text { I was disappointed because I had } \\
\text { to go to another store (s) to } \\
\text { complete my shopping trip }\end{array}$ & 3.83 & 3.91 & 6.18 & $69.775^{* * *}$ \\
\hline $\begin{array}{l}\text { This shopping trip was not a very } \\
\text { nice time out }\end{array}$ & 4.92 & 3.80 & 5.62 & $40.225^{* * *}$ \\
\hline Achievement & 4.14 & 3.91 & 5.70 & $129.427^{* * *}$ \\
\hline $\begin{array}{l}\text { I accomplished just what I wanted } \\
\text { to on this shopping trip }\end{array}$ & 4.28 & 4.02 & 5.75 & $48.021^{* * *}$ \\
\hline $\begin{array}{l}\text { While shopping, I found just the } \\
\text { item(s) I was looking for }\end{array}$ & 4.00 & 3.80 & 5.65 & $50.912^{* * * *}$ \\
\hline
\end{tabular}

Note:

-***p $<0.001 ; * * \mathrm{p}<0.01 ; * \mathrm{p}<0.05$ 
Table 5. Cluster Differences in the Dimensions of Mall Attributes

\begin{tabular}{|l|c|c|c|c|}
\hline & $\begin{array}{c}\text { Hedonic } \\
\text { shoppers } \\
\text { (n: 90) }\end{array}$ & $\begin{array}{c}\text { Apathetic } \\
\text { shoppers } \\
\text { (n:120) }\end{array}$ & $\begin{array}{c}\text { Utilitarian } \\
\text { Shoppers } \\
\text { (n: 90) }\end{array}$ & $F$ value \\
\hline Internal & 5.23 & 4.24 & 5.63 & $62.796^{* * *}$ \\
\hline $\begin{array}{l}\text { Having a superior mall } \\
\text { atmosphere }\end{array}$ & 5.55 & 4.26 & 5.31 & $28.768^{* * *}$ \\
\hline Having well-known brands & 5.89 & 5.04 & 5.57 & $18.144^{* * *}$ \\
\hline $\begin{array}{l}\text { Offering attractive design and } \\
\text { decoration }\end{array}$ & 5.35 & 4.25 & 5.06 & $26.614^{* * *}$ \\
\hline Having favourite specialty shops & 5.76 & 4.51 & 5.22 & $26.773^{* * * *}$ \\
\hline Making entertainment available & 5.36 & 3.81 & 5.06 & $54.153^{* * *}$ \\
\hline Being family friendly & 5.46 & 4.21 & 5.19 & $34.984^{* * *}$ \\
\hline Products & 5.63 & 4.82 & 6.00 & $36.528^{* * *}$ \\
\hline Offering quality of merchandise & 5.88 & 5.00 & 5.62 & $28.621^{* * * *}$ \\
\hline $\begin{array}{l}\text { Offering wide assortment of } \\
\text { merchandise }\end{array}$ & 5.89 & 4.94 & 5.59 & $27.046^{* * *}$ \\
\hline Delivering value for money & 5.26 & 4.31 & 4.78 & $11.010^{* * *}$ \\
\hline External & 5.37 & 4.88 & 5.49 & $3.679^{*}$ \\
\hline Being easy to parking & 5.25 & 5.07 & 5.45 & $.402^{\text {ns }}$ \\
\hline Providing security & 5.44 & 4.95 & 5.27 & $10.910^{\text {ns }}$ \\
\hline Providing access convenience & 5.51 & 4.96 & 5.24 & $6.403^{* *}$ \\
\hline
\end{tabular}

Note:

-***p $<0.001 ; * * \mathrm{p}<0.01 ; * \mathrm{p}<0.05$

In order to discern statistical differences among the three clusters with respect to mall visiting patterns, chi-square analysis was conducted. The results showed that the cluster groups presented significant differences except type of visit. The hedonic shoppers group visited malls more frequently than the other groups; for example, hedonic shoppers visited a mall once or more than once a week (73.3\%) compared with the utilitarian shoppers (55.7\%) and the apathetic shoppers (46.7\%). The number of companions slightly differentiated the groups: the hedonic (27.8\%) and apathetic shopper (27.5\%) groups visited malls with three and more companions than the utilitarian shopper group (21.6\%). In terms of duration of a mall visit, hedonic shoppers spent more time in the malls than other shopper groups: almost $97 \%$ of the hedonic shoppers spent more than one hour, compared with $85.2 \%$ of the utilitarian shoppers group and $72.5 \%$ of the apathetic shoppers group. Cluster groups also differed in terms of number of stores visited. The hedonic shoppers group visited more shops than other shopper clusters. More than half of the hedonic shoppers (54\%) visited more than five shops compared with 
nearly $37 \%$ of the utilitarian shoppers group and $26.2 \%$ of the apathetic shoppers group. Table 6 displays the cluster profiles based on the visiting patterns.

Table 6. Cluster Differences Based on the Mall Visiting Patterns

\begin{tabular}{|c|c|c|c|c|}
\hline Visiting patterns & $\begin{array}{c}\text { Hedonic } \\
\text { shoppers } \\
(\mathrm{n}: 90)\end{array}$ & $\begin{array}{c}\text { Apathetic } \\
\text { shoppers } \\
(\mathrm{n}: 120)\end{array}$ & $\begin{array}{c}\text { Utilitarian } \\
\text { Shoppers } \\
(\mathrm{n}: 90)\end{array}$ & $X^{2}$ value \\
\hline Type of visit & & & & $6.391^{\mathrm{ns}}$ \\
\hline Planned & $54(73.3)$ & $74(60.8)$ & $49(55.7)$ & \\
\hline Spontaneous & $22(26.7)$ & $47(39.2)$ & $39(44.3)$ & \\
\hline Frequency of visit & & & & $28.267^{* * *}$ \\
\hline Less than once a week & $24(26.7)$ & $64(53.3)$ & $39(44.3)$ & \\
\hline Once a week & $36(40.0)$ & $20(16.7)$ & $26(29.5)$ & \\
\hline Two and three times a week & $26(28.9)$ & $31(25.8)$ & $21(23.9)$ & \\
\hline More than three times a week & $4(4.4)$ & $5(4.2)$ & $2(2.3)$ & \\
\hline Number of companions & & & & $13.864^{*}$ \\
\hline None & $9(10.0)$ & $20(16.7)$ & $16(18.2)$ & \\
\hline $1-2$ & $56(62.2)$ & $67(55.8)$ & $53(60.2)$ & \\
\hline $3-4$ & $17(18.9)$ & $30(25.0)$ & $19(21.6)$ & \\
\hline 5 and more & $8(8.9)$ & $3(2.5)$ & $0(0.0)$ & \\
\hline Duration of visit & & & & $36.853^{* * *}$ \\
\hline Less than 1 hour & $3(3.3)$ & $33(27.5)$ & $13(14.8)$ & \\
\hline Between 1-2 hours & $36(40.0)$ & $60(50.0)$ & $38(43.2)$ & \\
\hline Between 2-3 hours & $36(40.0)$ & $22(18.3)$ & $25(28.4)$ & \\
\hline More than 3 hours & $15(16.7)$ & $5(4.2)$ & $12(13.6)$ & \\
\hline Number of stores visited & & & & $16.801^{* * *}$ \\
\hline 1-5 stores & $40(46.0)$ & $87(73.7)$ & $55(63.2)$ & \\
\hline $6-10$ stores & $37(42.5)$ & $26(22.0)$ & $26(29.9)$ & \\
\hline More than 10 stores & $10(11.5)$ & $5(4.2)$ & $6(6.9)$ & \\
\hline
\end{tabular}

Note:

-***p $<0.001 ; * * \mathrm{p}<0.01 ; * \mathrm{p}<0.05$

-Data in the parentheses show relative size of the groups as percentage. Data in the parentheses show relative size of the groups as percentage

Chi-square analysis was conducted to better understand clusters regarding whether there were statistical differences among the three clusters with respect to socio-economic variables. Of the demographic variables, gender and income level variables significantly differentiated the shopper groups. More than half of the apathetic shoppers (62.5\%) were composed of male visitors compared with the hedonic $(25.6 .7 \%)$ and the utilitarian 
shopper groups (21.6\%). Work status was another demographic variable differentiating the cluster groups. The hedonic shoppers cluster consists of an almost equal percentage of respondents from different work status groups, whereas the highest percentage of utilitarian (43.2\%) and apathetic shoppers (36.7\%) were from public and private sector employees. Table 7 exhibits the cluster profiles based on socio-economic characteristics.

Table 7. Cluster Differences Based on Socio-Demographic Characteristics

\begin{tabular}{|l|c|c|c|c|}
\hline & $\begin{array}{c}\text { Hedonic } \\
\text { shoppers } \\
(\mathrm{n}: 90)\end{array}$ & $\begin{array}{c}\text { Apathetic } \\
\text { shoppers } \\
(\mathrm{n}: 120)\end{array}$ & $\begin{array}{c}\text { Utilitarian } \\
\text { Shoppers } \\
(\mathrm{n}: 90)\end{array}$ & $X^{2}$ value \\
\hline Gender & & & & $35.333^{* * *}$ \\
\hline Male & $23(25.6)$ & $75(62.5)$ & $27(21.6)$ & \\
\hline Female & $67(74.4)$ & $45(37.5)$ & $61(69.3)$ & \\
\hline Age & & & & $5.610^{\mathrm{ns}}$ \\
\hline Younger than 20 & $15(16.7)$ & $21(17.5)$ & $10(11.4)$ & \\
\hline $20-29$ & $34(37.8)$ & $41(34.2)$ & $30(34.1)$ & \\
\hline $30-39$ & $19(21.1)$ & $17(14.2)$ & $20(22.7)$ & \\
\hline 40 and older & $22(24.4)$ & $41(34.2)$ & $28(31.8)$ & \\
\hline Education & & & & $2.915^{\text {ns }}$ \\
\hline Secondary and less & $19(21.1)$ & $25(20.8)$ & $12(13.6)$ & \\
\hline University & $52(57.8)$ & $67(55.8)$ & $58(65.9)$ & \\
\hline Masters and Ph.D. & $19(21.1)$ & $28(23.3)$ & $18(20.5)$ & \\
\hline Work status & & & & $12.738^{*}$ \\
\hline Self-employed & $17(18.9)$ & $28(23.3)$ & $11(12.5)$ & \\
\hline Public and private sector emp. & $28(31.1)$ & $44(36.7)$ & $38(43.2)$ & \\
\hline Retired, housewife or unemp. & $22(24.4)$ & $15(12.5)$ & $23(26.1)$ & \\
\hline Student & $23(25.6)$ & $33(27.5)$ & $16(18.2)$ & \\
\hline Note: & & &
\end{tabular}

Note:

$-* * * \mathrm{p}<0.001 ; * * \mathrm{p}<0.01 ; * \mathrm{p}<0.05$

-Data in the parentheses show relative size of the groups as percentage

\section{CONCLUSION}

This study provides an exploratory investigation of shopping motives of Lebanese mall shoppers and identified three clusters based on these motives. The primary purpose of this study was to investigate the shopping motivations of Lebanese mall visitors. The study results discovered three dimensions of shopping motivations: hedonic, achievement, and efficiency. This finding is in line with the study by Kim (2006). Second, the study segmented mall customers based on their shopping motivations and profiled them 
regarding mall attributes, visiting patterns, and socio-economic characteristics. These mall shopper groups could be summarized as follows:

Cluster 1: Hedonic shoppers (n: 100, 30\%). This group of shoppers scored the highest on hedonic shopping motivations. They were attracted by most of the mall attributes, especially having a wide assortment of merchandise and well-known brands, along with providing favorite speciality shops. More than two thirds of this group visited malls once a week or more. Most of them stayed in the malls for more than an hour and visited more than five shops. Nearly $75 \%$ of this group consisted of female shoppers with different occupations. Some studies have recognized hedonic shoppers. For example, Babin et al. (1994) divided shoppers into two groups: utilitarian and hedonic. Haanpaa (2005) also classified one of the shopper segments as hedonic shoppers. Teller et al. (2008) identified two groups of hedonic shoppers: pure hedonists and slight hedonists. Hedonic shoppers enjoy visiting malls for self-gratification, idea shopping, value shopping, social shopping, and role shopping. Mall managers targeting this group should focus on providing social facilities such as restaurants, cafes, and cinemas as well as well-known stores. Public places like toilets, gardens, and playgrounds are also important for hedonic shoppers.

Cluster 2: Apathetic shoppers ( $n: 120,40 \%$ ). This group of shoppers exhibited the lowest scores on every shopping motivation. They also had the lowest scores on all the mall attributes. More than half of this group visited malls less than once a week and stayed less than two hours. The majority of this shopper group visited one to five stores. The majority of the shoppers in this group was males and mostly private and public sector employees. Apathetic shoppers presented similar characteristics to apathetic shoppers, which were identified by Stone (1954) and Bellenger et al. (1977).

Cluster 3: Utilitarian shoppers ( $n$ : 90, 30\%). They had second highest scores on the accomplishment and efficiency. They also exhibited the second highest scores on each mall attribute. Almost $45 \%$ of this group visited malls less than once a week, and 58\% stayed less than two hours. More than half of this group also visited one to five shops. The majority of this group was female shoppers and mostly public and private sector employees. Utilitarian shoppers were also identified by other studies. For example, Kim (2006) labelled some shoppers as functional shoppers. Millan and Howard (2007) discovered strict and relaxed utilitarian shoppers. Gilboa (2012) recognized utilitarian shoppers. Malls focusing on this group of shoppers should prioritize different types of stores with a range of products and brands. Utilitarian shoppers also demand enough car parking facilities in order to shop and then leave a mall rapidly. 
The study findings indicated that Lebanese mall customers share similar characteristics with customers from different countries. One should, however, keep in mind that the local culture and economic development level of the country play a significant role in determining the Lebanese customers' shopping behavior. The study also demonstrated that segmentation is a useful tool for managers in identifying different mall customers and profiling them based on mall attributes, visiting patterns, and socioeconomic characteristics. Based on the segmentation, managers can easily develop their marketing plans and strategies in order to satisfy the needs of various mall customers.

This research has limitations, which should be dealt with in future works. First, this study investigated some variables that can be important for the mall shopping behavior. Further studies can integrate more variables to provide a more comprehensive understanding of mall shopping behavior in the Middle East. For example, experience shopping motives can be included in the study. Second, this study is an exploratory study aiming at clustering shoppers and finding out their characteristics instead of developing and testing hypotheses. However, further studies can develop and test hypotheses regarding the mall shopping behavior of Middle Eastern consumers. Third, further studies can employ samples from different countries such as Saudi Arabia, the United Arab Emirates, and Egypt to improve our understanding about Middle Eastern consumers. Finally, it would be interesting to compare the behavior of Middle Eastern consumers with that of other countries from other parts of the world to investigate the similarities and differences in a cross-cultural study.

\section{REFERENCES}

Anselmsson, J., (2006). Sources of customer satisfaction with shopping malls: a comparative study of different customer segments. International Review of Retail, Distribution and Consumer Research, 16(1) 115-138. https://doi.org/10.1080/09593960500453641

Arnold, M. J. \& Reynolds, K. E., (2003). Hedonic shopping motivations. Journal of Retailing, 79(2), 77-95. https://doi.org/10.1016/s0022-4359(03)00007-1

Babin, B. J., Darden, W. R. \& Griffin, M., (1994). Work and/or fun: Measuring hedonic and utilitarian shopping value. Journal of Consumer Research, 20(4), 644-656. https://doi.org/10.1086/209376

Bellenger, D. N., Robertson, D. H. \& Greenberg, B. A., (1977). Shopping center patronage motives. Journal of Retailing, 53(2), 29-38. 
Bloch, P. H., Ridgway, N. M. \& Dawson, S. A., (1994). The shopping mall as consumer habitat. Journal of Retailing, 70(1), 23-42. https://doi.org/10.1016/0022-4359(94) 90026-4

Blominvest Bank Report, (2015). Lebanese Malls Adopting the Philosophy of Build it! They Will Come!, Retrieved from

blominvestbank.com/wp-content/uploads/2015/08/Lebanese-Malls-Adopting-thePhilosophy-of----Build-it-They-Will-Come---1.pdf

Borges, A., Chebat, J-C, \& Babin, B.J., (2010). Does a companion always enhance the shopping experience?. Journal of Retailing and Consumer Services, 17(4), 294-299. https://doi.org/10.1016/j.jretconser.2010.02.007

Brunner, J. A. \& Mason, J. L., (1968). The influence of driving time upon shopping center preference. Journal of Marketing, 32(2), 57-61. https://doi.org/10.2307/1248929

Cai, Y. \& Shannon, R., (2012). Personal values and mall shopping behaviour: the mediating role of intention among Chinese consumers. International Journal of Retail and Distribution Management, 40(4), 290-317.

https://doi.org/10.1108/09590551211211783

Chebat, J. C., Sirgy, M. J. \& Grzeskowiak, S., (2010). How can shopping mall management best capture mall image?. Journal of Business Research, 63(7), 735740. https://doi.org/10.1016/j.jbusres.2009.05.009

Cherrier, H., Rahman, K., Mady, T. \& Lee, D., (2009). The globalization of Arab world: impacts on consumers' level of materialism and vanity, World Journal of Management, 1(1), 82-94. https://doi.org/10.17485/ijst/2016/v9i1/78563

Cox, W.E. Jr. \& Cooke, E.F., (1970). Other dimensions involved in shopping center preference. Journal of Marketing, 34(4), 12-17. https://doi.org/10.1177/002224297003400403

Damian, D.S., Curto, J. D. \& Pinto, J.C., (2011). The impact of anchor stores on the performance of shopping centres: the case of Sonae Sierra. International Journal of Retail and Distribution Management, 39(6), 456-475. https://doi.org/10.1108/09590551111137994

Dibb, S., Stern, P. \& Wensley, R. (2002), "Marketing knowledge and the value of segmentation", Marketing Intelligence \& Planning, 20(2), 113-119. https://doi.org/10.1108/02634500210418536

El Hedhli, K., Zourrig, H. \& Chebat, J-C., (2016). Shopping well-being: Is it just a matter of pleasure or doing the task? The role of shopper's gender and self-congruity. Journal of Retailing and Consumer Services, 31(1), 1-13. 
https://doi.org/10.1016/j.jretconser.2016.03.002

El-Adly, M. I., (2007). Shopping malls attractiveness: a segmentation approach. International Journal of Retail and Distribution Management, 35(11), 936-950. https://doi.org/10.1108/09590550710828245

El-Adly, M.I. \& Eid, R., (2015). Measuring the perceived value of malls in a non-western context. International Journal of Retail and Distribution Management, 43(9), 849869. https://doi.org/10.1108/ijrdm-04-2014-0045

Farrag, D.A., El Sayed, I.M. \& Belk, R.W., (2010). Mall shopping motives and activities: A multimethod approach. Journal of International Consumer Marketing, 22(2), 95115, https://doi.org/10.1080/08961530903476113

Finn, A., (1996). Shopping center image, consideration, and choice: Anchor store contribution. Journal of Business Research, 35(3), 241-251.

https://doi.org/ 10.1016/ 0148-2963(95)00129-8

Frasquet, M., Gil, I. \& Molla, A., (2001). Shopping-centre selection modelling: A segmentation approach. International Review of Retail, Distribution and Consumer Research, 11(1), 23-38. https://doi.org/10.1080/09593960010004707

Gilboa, S. (2009). A segmentation study of Israeli mall customers, Journal of Retailing and Consumer Services, 16(2), 135-144. https://doi.org/10.1016/j.jretconser.2008. 11.001

Gilboa, S. \& Vilnai-Yavetz, I., (2012). Segmenting multicultural mall visitors: The Israeli case. Marketing Intelligence and Planning, 30(6), 608-624.

https://doi.org/10.1108/02634501211262582

Gonzalez-Hernandez, E.M. \& Orozco-Gomez, M., (2012). A segmentation study of Mexican consumers based on shopping centre attractiveness. International Journal of Retail and Distribution Management, 40(10), 759-777.

https://doi.org/10.1108/09590551211263173

Haanpaa, L. (2005), Shopping for fun of for needs? A study of shopping values, styles and motives of Finnish consumers in 2001-2003. Proceeding of the 7th Conference of European Sociological Association, Torun, Poland, September 9-12.

Hair, J. F., Jr., Black, W.C., Babin, B.J., \& Anderson, R. L. (2014), Multivariate Data Analysis, 7th Ed. London, England: Pearson Education Limited, Essex.

Jackson, V., Stoel, L. \& Brantley, A., (2011). Mall attributes and shopping value: Differences by gender and generational cohort. Journal of Retailing and Consumer Services, 18(1), 1-9. https://doi.org/10.1016/j.jretconser.2010.08.002 
Khong, K. W. \& Ong, F.S., (2014). Shopper perception and loyalty: A stochastic approach to modelling shopping mall. International Journal of Retail and Distribution Management, 42(7), 626-642. https://doi.org/10.1108/ijrdm-11-2012-0100

Kim, H. S., (2006). Using hedonic and utilitarian shopping motivations to profile inner city consumers. Journal of Shopping Center Research, 13(1), 57-79.

Kuruvilla, S. J. \& Joshi, N., (2010). Influence of demographics, psychographics, shopping orientation, mall shopping attitude and purchase patterns on mall patronage in India. Journal of Retailing and Consumer Services, 17(4), 259-269. https://doi.org/10.1016/j.jretconser.2010.02.003

Lee, S. L., Ibrahim, M. F. \& Hsueh-Shan, C., (2005). Shopping-centre attributes affecting Male shopping behaviour. Journal of Retail and Leisure Property, 4(4), 324-340. https://doi.org/10.1057/palgrave.rlp.5090230

Li, F., Zhou, N., Nicholls, J. A. F., Zhuang, G. \& Kranendonk, C., (2004). Interlinear or Inscription? A comparative study of Chinese and American mall shoppers' behaviour. Journal of Consumer Marketing, 21(1), 51-61.

https://doi.org/10.1108/07363760410513969

Lotz, S. L., Eastlick, M. A., Mishra, A. \& Shim, S., (2010). Understanding patrons' participation in activities at entertainment malls. International Journal of Retail and Distribution Management, 38(6), 402-422.

https://doi.org/10.1108/09590551011045366

Mas-Ruiz, F. J., (1999). Image of suburban shopping malls and two-stage versus uniequational modelling of the retail trade attraction. European Journal of Marketing, 33(5/6), 512-530. https://doi.org/10.1108/03090569910262071

McDonald, M. \& Dunbar, I. (2012). Market Segmentation: How to Do it and How to Profit from It, $4^{\text {th }}$ edition, John Wiley $\&$ Sons, Chichester. https://doi.org/10.1002/9781119207863

Michon, R., Yu, H., Smith, D. \& Chebat, J-C., (2008). The influence of mall environment on female fashion shoppers' value and behaviour. Journal of Fashion Marketing and Management, 12(4), 456-468. https://doi.org/10.1108/13612020810906128

Millan, E.S. \& Howard, E., (2007). Shopping for pleasure? Shopping experiences for Hungarian consumers. International Journal of Retail and Distribution Management, 35(6), 474-487. https://doi.org/10.1108/09590550710750340

Mottu, E. \& Nakhle, N. (2010). Lebanon: Real GDP Growth Analysis, International Monetary Fund Resident Representative Office in Lebanon. 
Nicholls, J., Fuan L., Kranendonk, C., \& Roscow, S. (2002), “The Seven Year Itch? Mall Shopping Over Time,” Journal of Consumer Marketing, 19(2), 149-165. https://doi.org/10.1108/07363760210420568

Nicholls, J.A.F., Roslow, S. \& Dublish, S., (1997). Time and companionship: key factors in Hispanic shopping behaviour. Journal of Consumer Marketing, 14(3), 194-205. https://doi.org/10.1108/07363769710166783

Punj, G. \& Steward, D. W., (1983). Cluster analysis in marketing research: Review and suggestions for application. Journal of Marketing Research, 20(2), 134-148. https://doi.org/10.2307/3151680

Ruiz, J.P., Chebat, J.C. \& Hansen, P., (2004). Another trip to mall: a segmentation study of customers based on their activities. Journal of Retailing and Consumer Services, 11(6), 333-350. https://doi.org/10.1016/j.jretconser.2003.12.002

Shanmugan, R., (2013). Anchor-store quality in malls: an economic analysis. International Journal of Retail and Distribution Management, 41(2), 90-112. https://doi.org/10.1108/09590551311304301

Sharif, A. (2017), "How Lebanon is One of Middle East's Strongest Fashion Hubs", Culture Trip, Accessed October 11, 2018. Retrieved from https://theculturetrip.com/middle-east/lebanon/articles/how-lebanon-is-one-ofmiddle-easts-strongest-fashion-hubs/

Sherlock, R. (2015), "War is a million miles away when the Lebanese begin to party" Telegraph, Accessed October 11, 2018. Retrieved from https://www.telegraph.co.uk/news/worldnews/middleeast/lebanon/11748872/Waris-a-million-miles-away-when-the-Lebanese-begin-to-party.html

Singh, H. \& Sahay, V., (2012). Determinants of shopping experience: Exploring the mall shoppers of national capital region (NCR) of India. International Journal of Retail and Distribution Management, 40(3), 235-248.

https://doi.org/10.1108/09590551211207184

Sit, J. K. \& Birch, D., (2014). Entertainment events in shopping malls-profiling passive and active participation behaviours. Journal of Consumer Behaviour, 13(6), 383-392. https://doi.org/10.1002/cb.1487

Sit, J., Merrilees, B. \& Birch, D., (2003). Entertainment-seeking shopping centre patrons: the missing segments. International Journal of Retail and Distribution Management, 31(2), 80-94. https://doi.org/10.1108/09590550310461985

Southworth, M., (2005). Reinventing Main Street: From Mall to Townscape Mall. Journal of Urban Design, 10(2), 151-170. https://doi.org/10.1080/13574800500087319 
Stone, G.P., (1954). City shoppers and urban identification: observation on the social psychology of city life. American Journal of Sociology, 60(1), 36-45. https://doi.org/10.1086/221483

Tandon, A., Gupta, A., \& Tripathi, (2016). Managing shopping experience through mall attractiveness dimensions: an experience of Indian metro cities. Asia Pacific Journal of Marketing and Logistics, 28 (4), 634-649.

https://doi.org/10.1108/apjml-08-2015-0127

Tauber, E. M., (1972). Why do people shop. Journal of Marketing, 36(4) 46-59. https://doi.org/10.2307/1250426

Teller, C., Reutterer, T. \& Schnedlitz, P., (2008). Hedonic and utilitarian shopper types in evolved and created retail agglomerations. International Review of Retail, Distribution and Consumer Research, 18(3), 283-309.

https://doi.org/10.1080/09593960802113877

Terblanch, N.S., (1999). The perceived benefits derived from visits to a super-regional shopping centre: an exploratory study. South African Journal of Business Management, 30(4), 141-146.

Wong, C.B., Ng, H.C. Wong, K. K. L. \& Wong, M.H., (2012). The relationship between shopping mall attributes, customer satisfaction and positive word-of-mouth: China visitors in Hong Kong. Global Journal of Management and Business Research, 12(3), 49-62.

Yankelovich, D. \& Meer, D. (2006). Rediscovering market segmentation. Harvard Business Review, 84(2), 122-131.

Yilmaz, V., (2004). Consumer behaviour in shopping centre choice. Social Behaviour and Personality, 32(8), 783-790.

Dr. Mehmet Haluk Koksal is professor of marketing and an independent business consultant, advising creative start-ups regarding their next steps. After receiving his Ph.D. from University of Exeter, England, he worked as an assistant professor of marketing in Turkey and Lebanon. He also worked in United Arab Emirates as a professor of marketing. Before joining academia, he worked for several companies including Coca-Cola Export Corporation. Dr. Koksal's research mainly revolves around consumer behaviour, retailing, marketing strategy, and digital marketing. His articles have been published in internationally-recognized journals, a book chapter, and many international and national conference proceedings. 